\title{
Does product market competition increase strike activity? Evidence from the UK
}

\author{
George Symeonidis
}

University of Essex

\begin{abstract}
Although many studies have examined the effect of labour market characteristics, macroeconomic fluctuations and workplace-level factors on strike activity, much less is known about industry-level determinants of industrial conflict, and in particular the role of product market competition. I examine the effect of competition on strike activity using evidence from a natural experiment of policy reform, the introduction of cartel legislation in the UK in the late 1950s. My econometric analysis, which takes advantage of the fact that different industries were affected to varying degrees by cartel policy, establishes that both the number of strikes and the number of working days lost as a result of strikes increased significantly when competition intensified after the abolition of cartels. I propose an interpretation of these results with reference to theoretical models of bargaining with asymmetric information.
\end{abstract}

JEL classification: J5, L1

Keywords: competition, cartels, labour market, strikes, UK industry

Address for correspondence: Department of Economics, University of Essex, Wivenhoe Park, Colchester CO4 3SQ, U.K.

E-mail: symeonid@essex.ac.uk

Acknowledgments: I am grateful to two anonymous referees for very helpful comments and suggestions. 


\section{Introduction.}

Although many empirical studies have examined the effect of labour market characteristics, macroeconomic fluctuations and workplace-level factors on strike activity, much less is known about industry-level determinants of industrial conflict, and in particular the role of product market competition. This paper tries to fill this gap. I examine the effect of competition on strikes using evidence from a unique natural experiment of policy reform, the introduction of cartel law in the UK in the late 1950s. My analysis takes advantage of the exogeneity of cartel policy and the fact that this affected different industries to varying degrees. The results, using a panel data set of 50 industries over a 27-year period, both before and after the implementation of cartel policy, reveal a strong positive effect of the intensification of competition caused by the abolition of cartels on the number of strikes as well as on the working days lost as a result of strikes. I also propose an interpretation of these findings with reference to theoretical models of bargaining with asymmetric information.

The existing literature offers little and contradictory evidence regarding the impact of competition on industrial conflict. Geroski et al. (1982) and Geroski and Knight (1983) have found a positive association of market concentration with strike frequency but a negative one with strike duration in the UK. For the USA, in contrast, Tracy $(1986,1987)$ reports a positive effect of concentration on strike probabilities and no effect on duration, whereas Abowd and Tracy (1989) have found no link of strike incidence with concentration and a negative one with import penetration. Brandl and Traxler (2010) present evidence of a negative association of economic openness (the sum of exports and imports as a percentage of GDP) with working days lost due to stoppages for a panel of 19 OECD countries, which disappears 
when they include year dummies in their regression. These results are not only ambiguous but also difficult to interpret because of methodological limitations and the lack of a clear theoretical foundation. The main problem is that variables such as concentration or imports are endogenous. Furthermore, concentration may be even positively rather than negatively related to the intensity of competition (Sutton 1991, Symeonidis 2000, 2002), whereas economic integration may also have a market expansion effect or otherwise involve more than just an intensification of competitive conduct. A further drawback is the lack of a convincing theoretical justification in the literature for a role of product market competition in industrial conflict other than as a determinant of the level of firm profitability, even though profitability is often included as a separate regressor in empirical models of strike activity.

Few studies of industrial action in Britain have made use of panel data, and to the best of my knowledge none exists for the time period I consider here. Timeseries studies have obtained ambiguous results for standard explanatory variables such as the unemployment rate, the inflation rate or profitability (Pencavel 1970, Knight 1972, Shorey 1977). Cross-section analyses, including Shorey (1976) and Smith et al. (1978), have found little evidence of a consistent effect of variables such as unemployment or unionisation on inter-industry differences in strike intensity. Perhaps the most consistent finding across time-series studies is a negative effect of past wage increases on strike frequency. However, cross-section results have often revealed a positive association between earnings and industrial conflict. In this paper I confirm that many of these factors do not contribute much to explaining the evolution of strike incidence in British industries during the period examined, once one controls for product market competition as well as industry and time effects. 
Strikes will always make headlines because they can cause serious disruption and economic loss, despite the decline in industrial conflict in many countries over the past few decades. Airport workers in several European countries have regularly been on strike in recent years, and industrial action by French transport workers caused considerable disruption during the European football championship in the summer of 2016. An Indian one-day general strike in September 2016 was called “the biggest industrial action in human history” by the country’s unions and several international media. The number of stoppages in China increased tenfold between 2011 and 2015 according to the China Labour Bulletin, a non-governmental organisation based in Hong Kong that promotes workers' rights in China, and was still on the rise in the first half of 2016. In December 2016 some relatively minor disputes in Britain, affecting railways and postal services, and coming after industrial action by teachers and junior doctors earlier in the year, were somewhat hastily dubbed "the Christmas of discontent” by the media. Although it is perhaps too early to assess the long-term significance of these events, they have also come as a reminder that there are still many unanswered questions in the literature on industrial disputes.

In fact, this literature presents a paradox. There are several different theories of the causes of conflict, but none has obtained strong empirical support (see the surveys and/or critical discussions by Kennan 1986, Kaufman 1992, Card 1990, Mumford 1993, Ingram et al. 1993, Franzosi 1989, and Cramton and Tracy 2003, among others). Moreover, some of the most sophisticated and widely accepted theoretical models, such as those based on the existence of asymmetric information between employers and unions, seem to have difficulty explaining one of the most remarkable and well documented facts about industrial disputes: the large differences in strike activity across industries, time periods and countries (described, 
among others, by Kerr and Siegel 1954, Durcan et al. 1983, Smith et al. 1978, Kaufman 1982, Rimlinger 1959, van der Velden et al. 2007, and Brandl and Traxler 2010). No attempt will be made to fully resolve these issues in the present research. Differences in strike activity across British industries and over time will be simply controlled for using a full set of industry and year dummies. However, I will argue that the estimated strong positive effect of product market competition on industrial disputes provides support for the asymmetric information model of strikes, thus strengthening the case for economic theories of rational bargaining as compared to alternative economic models or behavioural, political and organisational approaches.

\section{Competition in British industry.}

Explicit restrictive agreements among firms were widespread in British industry in the mid-1950s: nearly half of manufacturing and many services industries were subject to price-fixing. The agreements were not enforceable at law, but they were not illegal. Most of them provided for minimum or fixed producer prices. There were generally no restrictions on longer-term decisions such as investment in capacity, advertising or R\&D expenditure. A description of the institutional changes and the evolution of competition from the 1950s to the early 1970s and a detailed survey of restrictive agreements across all British manufacturing industries can be found in Symeonidis (2002). Here I summarise the evidence and I describe the construction of the competition data for this paper.

The 1956 Restrictive Trade Practices Act required the registration of restrictive agreements, including verbal or even implied arrangements, on goods. Registered agreements should be abandoned, unless they were either successfully defended by the parties in the newly created Restrictive Practices Court as producing 
benefits that outweighed the presumed detriment or cleared by the Registrar of Restrictive Trading Agreements as not significantly affecting competition. Because the attitude of the Court could not be known until the first cases had been heard, the large majority of industries registered their agreements rather than dropping or secretly continuing them. The first agreements came before the Court in 1959 and were struck down. This induced most industries to voluntarily abandon their agreements rather than incur the costs of a Court case with little hope of success.

Were the agreements effective? This depended on two factors: the extent to which the parties themselves conformed to them and the extent of competition from outside firms, domestic or foreign. Evidence from the registered agreements, several industry reports published by the Monopolies and Restrictive Practices Commission during the 1950s, the Political and Economic Planning (1957) survey of industrial trade associations and a large number of case studies discussed in Swann et al. (1973, 1974) suggests that in most industries the agreements had been operated effectively prior to cancellation, the parties typically accounted for a large fraction of the market and contained the largest and best-known domestic firms, and outside competition was usually weak. For instance, Swann et al. report cartel market shares of $90 \%$ or higher in about two thirds of the 40 industries they examine, and $75 \%$ or higher in all but two cases. Competition from imports was often limited as a result of tariffs and quantitative controls, differing technical standards, transport costs or international restrictive agreements. Finally, the legality of the agreements and the institutional role of the trade associations that operated them had facilitated the coordination, monitoring and enforcement of collusion.

To what extent did collusion break down following the abolition of cartels? Evidence from various sources indicates that price competition intensified after 1958 in 
many industries. However, in many others, agreements to exchange information on prices, price changes and so on replaced the former explicit collusive arrangements, and price competition emerged only after these information agreements were abandoned in the mid-1960s, following adverse decisions of the Restrictive Practices Court. Price wars occurred in a number of previously collusive industries in the second half of the 1960s, and the final blow came with the provisions of the 1968 Restrictive Trade Practices Act regarding information agreements. In many industries, therefore, competition emerged more than a decade after the introduction of the 1956 legislation. Overall, sooner or later the large majority of industries with collusive agreements in the 1950s did experience a breakdown of collusion as a result of the 1956 Act.

Although my main source of information on competition are the agreements registered under the 1956 Act, I also use other sources to identify unregistered agreements, including the industry reports of the Monopolies Commission, the 1955 Monopolies Commission report on collective discrimination, the 1949 report of the Lloyds' Committee on resale price maintenance, industry studies contained in Burn (1958) and Hart et al. (1973), the Board of Trade annual reports from 1950 to 1956, and the Political and Economic Planning (1957) survey of trade associations (including unpublished background material for this survey). The use of a diverse range of sources guarantees that any measurement error caused by ineffective agreements or unknown cases of collusion in the data is very small.

My data set for this paper is a panel of 50 industries or industry groups covering all economic activity in Britain. The industry definitions are those used in the official strike statistics. My approach to modelling the effect of competition is based on calculating the extent to which any given industry in the panel was affected by the 1956 Act. Several industries were not affected at all: some had always been 
competitive, others were under public ownership, and a few had collusive agreements which continued throughout the period under study. The majority of industries were affected to a larger or smaller extent, and for each of these I have calculated the fraction of sales revenue covered by products which were subject to significant restrictive agreements abandoned as a result of the 1956 cartel law. Not all agreements had an impact on competition, so I have taken the types of restrictions into account when determining the extent to which any given industry was collusive in the 1950s and I have excluded cases where the effect of the restrictions on prices would have been minimal. The geographical coverage of each agreement was also taken into account. A variable, CHANGE, was then defined, which takes values between 0 and 1 according to the fraction of each industry which was affected by the legislation. My method of constructing CHANGE is illustrated in the Appendix by way of a few examples. ${ }^{1}$ The main limitation of CHANGE is that it does not capture variations in the "degree of collusion" across industries, since this cannot be determined from the available information. Note that to the extent that any measurement error in CHANGE is not correlated with industry characteristics affecting strike intensity, my econometric results may only understate somewhat the magnitude of the effect of competition on industrial action. The mean of CHANGE across the 50 industries in my data set is 0.27 and its standard deviation 0.27. Excluding the 18 industries for which it takes the value 0 (no significant agreements cancelled), the mean of CHANGE is 0.43 , the standard deviation 0.23 , the minimum 0.10 and the maximum 0.80 .

The panel spans 27 years, from 1949 to 1975. Official data on strike activity by industry are only available since 1949. In any case, the British economy only gradually

\footnotetext{
${ }^{1}$ Further details, for each industry in the sample, are provided in the Additional Materials posted on the EER website.
} 
emerged from wartime controls, and these would have affected both product market competition and strike activity before 1949. Furthermore, a significant further change in cartel policy occurred in the UK in the mid-1970s, when the 1976 Restrictive Practices Act led to the breakdown of restrictive agreements in services. I have chosen 1975 as the last year in my panel because it seemed preferable to avoid the additional complication of a change in competition regime other than the 1956 Act affecting a number of industries in the data set. The period 1949-1975 was characterised by considerable stability in labour market institutions and policy, except for the operation of prices and incomes policy between 1965 and the early 1970s. There was also macroeconomic stability for most of the period, except for an upward trend in inflation after the late 1960s and the 1973-1975 recession. All in all, the 1956 cartel legislation stands out as one of the major exogenous influences on the economic environment facing British industries during the period under study.

\section{Endogenous variables and descriptive statistics.}

Official statistics for the number of stoppages beginning in each year and the number of working days lost as a result of stoppages in progress during each year in about 50 individual industries or industry groups covering the whole British economy have been published since 1949 in the Ministry of Labour Gazette and its successors, the Employment and Productivity Gazette and the Department of Employment Gazette. For the 1950s and most of the 1960s these are the only available data on stoppages in UK industries. Workplace-level data are not available before the 1980s. The number of industries covered each year ranges from 48 to 50 because of minor changes in industry definitions and the occasional splitting or merging of categories. It was therefore sometimes necessary to make small adjustments to the figures to ensure comparability 
over time. Two thirds of the industries are in manufacturing, and more than four fifths were fully or largely under private ownership during the period examined.

Some of the industry definitions are broad, whereas others are finer. This could potentially raise the concern that certain large industry groups are given the same weight in the analysis as some small individual industries. However, there are at least two factors that help alleviate this concern, both of which indicate that the classification is generally well suited for the analysis of strikes. First, most definitions coincide with those used by Bain and Price (1980) to study unionisation, which suggests that union coverage and organisation was a significant criterion in defining the industry categories for the stoppage data, as seems appropriate. Second, the level of aggregation is often lower for strike-prone than for other sectors.

The data are for stoppages that arise primarily over terms and conditions of employment. Strikes for political reasons, such as those called in opposition to the 1971 Industrial Relations Act, are excluded. No distinction is made between strikes and lockouts. However, since the vast majority of these stoppages are strikes, I will use the two terms interchangeably. Stoppages involving fewer than 10 workers or lasting less than one day are not recorded unless the aggregate number of working days lost is higher than 100. This implies that in those few cases where figures for the number of strikes and the number of days lost for a certain industry and year are not reported in the Gazette, it is difficult to know whether these were very small or exactly zero. Note that the working days lost refer to the workplaces where stoppages took place - not in other workplaces, for instance through shortage of materials. About half of all stoppages and 80\% of days lost during the period 1949-1975 were over 
pay issues, with most of the rest concerning manning levels or dismissal and discipline (Durcan et al. 1983, Smith et al. 1978). ${ }^{2}$

My two measures of strike activity are standard and have been widely used in the previous literature. Although the number of stoppages can be influenced by very short strikes with little economic significance and the number of days lost can be influenced by even a single unusually long strike, the two measures together give an accurate account of the extent of industrial conflict in any given industry and year. For purposes of comparison and analysis it is useful to normalise them by dividing with the number of employees, so I will define STRIKES, the number of stoppages per 100,000 employees, and DAYS, the number of working days lost per 1000 employees, following standard practice and using data on employees in employment for each industry and year from the Ministry of Labour Gazette and the Annual Abstract of Statistics.

Even a casual look at the data reveals considerable variation in strike activity over time and across industries. For instance, the total number of stoppages in the UK varies between 1,339 in 1950 and 3,116 in 1969, and the total number of working days lost ranges from 1.39 million in 1950 to 23.9 million in 1972 . These aggregate figures reflect an upward trend in both STRIKES and DAYS for much of the 27-year period, with a peak in the late 1960s and early 1970s. This can be seen in Table 1, which contains descriptive statistics for STRIKES and DAYS for five different sub-periods and also confirms that the sharp rise in the aggregate number of disputes and days lost in Britain during the 1960s and 1970s was not driven by a

\footnotetext{
${ }^{2}$ Smith et al. (1978), who had access to unpublished data held at the UK Department of Employment, report cross-section regression results for the determinants of stoppage frequency in UK industries using averages for 1968-1973 both for all stoppages and for the subset of stoppages over pay issues. The results are very similar in the two cases.
} 
few outlier industries. For instance, the median number of stoppages per 100,000 employees across the 50 industries was six times larger, and the median number of working days lost per 1000 employees more than ten times larger, in 1971-1975 than in 1954-1958.

Furthermore, almost half of all industrial action throughout this period was concentrated in four industries, which together accounted for only $5-10 \%$ of total employment: coal mining, motor vehicles and cycles, shipbuilding and marine engineering, and port and inland water transport (see also Durcan et al. 1983, Smith et al. 1978). The extent of variation in strike incidence across industries decreased after the mid-1960s for two main reasons: the relative decline of strike activity in coal mining and the spreading of conflict in several previously little-affected industries. However, the ranking of industries with respect to strike intensity remained relatively stable over the entire period. This implies that whatever the causes of the heterogeneity across industries and over time, this can be largely captured in a regression model by industry and time effects. Since the distributions of the number of stoppages and the number of days lost across industries are both highly skewed to the right - in a typical year, the former has a maximum value of several hundred and a median of less than 10, and the latter has a maximum of several hundred thousand and a median of less than 10,000 - I use logarithmic and other transformations of my endogenous variables in the econometric analysis of the next section.

Note that strikes are rare events even in strike-prone industries and typically affect only a small fraction of workplaces in any given year. One could argue, however, that a change in a certain industry-level variable may affect the propensity of conflict in all or most workplaces even though this propensity is actually translated into stoppages 
only at a minority of workplaces. A further implicit assumption of studies using data at the industry (or country) level is that the strike-affected workplaces have the same characteristics with regard to any explanatory variable as the average workplace in their industry (or country). This assumption is plausible with respect to CHANGE in the present context: the change of competition regime caused by the abolition of the British cartels affected the large majority of firms in the previously collusive industries.

Descriptive statistics for strike activity in manufacturing industries are reported in Table 2 . There are obvious benefits to using all the available information in the econometric analysis, especially since the sample is not large. On the other hand, a potential concern is that any effect of competition on industrial action might have been qualitatively or quantitatively different in manufacturing than in the rest of the economy during the period examined. For instance, nearly all British industries fully or largely under public ownership during this period were outside manufacturing. Not only were publicly owned firms likely to be facing softer financial constraints than privately owned ones, but also bargaining structures differed: local or plantlevel decentralised bargaining was much more prevalent in the private than in the public sector. Furthermore, as pointed out in the previous section, the 1956 cartel law only applied to the production of goods. In fact, only 5 out of the 34 manufacturing industries in the panel were totally unaffected by cartel policy, whereas CHANGE is equal to zero for 13 out of 16 non-manufacturing industries, including those under public ownership. In short, the manufacturing sub-sample has a more symmetric distribution of CHANGE than the full sample and also excludes public-sector industries where the large majority of employees were covered by national collective agreements only. 
However, a comparison of Tables 1 and 2 reveals only small differences in the evolution of STRIKES and DAYS between the full sample and the manufacturing sub-sample. Strike intensity increased sharply during the 1960s and early 1970s in manufacturing as in the British economy as a whole, and this increase was only slightly greater in manufacturing than in the rest of the economy - a difference which is not driven by outliers, since it is more evident in the median than the mean of STRIKES and DAYS, and is only partly explained by the relative decline of conflict in coal mining after a peak in the late 1950s. The lower standard deviations in Table 2 relative to Table 1 are partly due to the exclusion of two strike-intensive industries, port and inland water transport and coal mining, from Table 2.

Table 3 reports correlation coefficients between CHANGE, $\operatorname{lnSTRIKES}$ and lnDAYS for five sub-periods. I split the ten years in the data set before the implementation of the 1956 Restrictive Trade Practices Act into two sub-periods, 1949-1953 and 1954-1958, in order to also check whether the time trend in strike activity before the implementation of the cartel law was significantly different in industries with higher value of CHANGE than in those with lower value of CHANGE. I also consider three sub-periods after 1958 so as to distinguish between short-run and long-run effects of cartel policy: 1959-1964, 1965-1970 and 1971-1975. The exact choice of years for defining these sub-periods has very little effect on the overall pattern of results shown in Table 3. Note that the sign of any one of these correlation coefficients is not informative with respect to the competition-strike intensity relationship, since CHANGE may be correlated with unobserved industry characteristics that affect strike activity. For instance, only one of the four most strikeprone industries mentioned above was significantly affected by the 1956 cartel law, yet this does not tell us very much about the link between competition and strike propensity 
- other factors, economic and institutional, were probably responsible for the high level of conflict in these industries (Durcan et al. 1983). What is far more important is the way the correlations change over time.

It can be seen that the correlation coefficients of CHANGE with $\ln S T R I K E S$ and $\ln D A Y S$ for the full sample are both slightly negative in the 1950s. For instance, in 1954-1958, the period immediately preceding the implementation of the 1956 Act, they are -0.046 and -0.090 , respectively. However, they both turn positive in the 1960 s and even more so in the 1970s: in 1971-1975 the corresponding values are 0.206 and 0.123 . In other words, industries which experienced more extensively a change in competition regime as a result of the 1956 Act tended to be slightly less strike-prone in the 1950s than industries which were less affected by the legislation, but this association completely reversed in the 1960s and 1970s. This reversal is a strong indication that the intensification of product market competition after the breakdown of cartels caused an increase in strike activity in the short run as well as in the long run.

It can also be seen from Table 3 that the negative correlation of CHANGE with $\ln S T R I K E S$ and $\ln D A Y S$ in the 1950s was stronger for manufacturing than for the entire economy. However, what is more significant is that the correlation coefficients for manufacturing and for the whole economy change in a similar way over time, and they all eventually become positive in the 1960s. Note that in the early 1970s there was a slight reversal of the trend for $\ln D A Y S$, although not for $\ln S T R I K E S$, in manufacturing, a pattern not observed in the full sample. Still, the magnitude of the overall change in the correlation coefficients between the 1950s and the 1970s is similar in manufacturing and the economy as a whole. Thus the evidence from the descriptive statistics is that manufacturing was not significantly different from the rest of the economy with respect to the effect of competition on industrial action. 
A potential objection is that different industries may have been subject to different time trends in strike activity during the 1950s, which persisted in later years, so that the link between CHANGE and the evolution of strike intensity that we observe in the data may be to some extent due to the continuation of these trends rather than indicate an effect of competition. However, a comparison of 1949-1953 with 1954-1958 shows that this is not the case. For $\ln S T R I K E S$ the correlation with CHANGE actually becomes more negative in the later sub-period, whereas for $\ln D A Y S$ it becomes less negative, and in both cases the change is small relative to the increase in both correlation coefficients after 1958. In short, there is no evidence of a link between CHANGE and the evolution of strike activity in the 1950s, a time when the British cartels were still in place. It therefore seems safe to conclude that any association between CHANGE and the evolution of $\ln S T R I K E S$ and $\ln D A Y S$ after 1958 is not biased by any pre-existing trend differentials across industries. ${ }^{3}$

\section{Econometric model and results.}

My econometric approach in this paper is a variation on the difference-in-differences methodology, which consists in comparing the difference between the average change in the variable of interest in an experimental group and the average change in the same variable in a control group. Instead of two distinct groups, however, what we have in the present case is a continuum of industries characterised by the extent to which they were affected by the 1956 cartel law, including a considerable number which were not affected at all. The specifications used are panel data models with individual-specific (industry) effects. This allows me to control for unobserved industry characteristics

\footnotetext{
${ }^{3}$ Further evidence on the evolution of $\ln S T R I K E S$ and $\ln D A Y S$ over time for three groups of industries, according to the value of the variable CHANGE, is provided in a series of graphs in the Additional Materials posted on the EER website.
} 
which may be important for strike activity and are relatively stable over time. Year dummies will also be included among the regressors to control for economy-wide factors that may have influenced the evolution of industrial disputes during the period examined. For instance, the increasing unwillingness of British governments to become involved in collective bargaining through the operation of official dispute resolution after the late 1950s (Durcan et al. 1983) and the gradual rise in the inflation rate and the practice of incomes policy after the mid-1960s may help explain the two biggest jumps in strike activity during this period, the first in 1960 and the second in 1968.

To the extent that there is a link between product market competition and industrial conflict, the progressive opening of the British economy after the mid1960s may have also been a factor. This effect, which is difficult to measure in a fully satisfactory way, should be partly picked up by the time dummies. Furthermore, there is no evidence that changes in the extent of foreign competition are correlated with CHANGE, at least for the subset of manufacturing industries. As shown in Symeonidis (2003), cartelisation was not correlated with the intensity of foreign competition in the 1950s. Moreover, Kitchin (1976) provides estimates of effective tariff protection for 1963 and 1968 for manufacturing industries. Effective protection increased in 6 out of 12 industries or sectors that had been mostly collusive in the 1950s and therefore experienced a change of competition regime during the 1960s, and decreased in the other 6 . For industries or sectors that had been mostly competitive and were therefore not much affected by cartel policy, the respective numbers are 8 and 10 . Tariff protection changes before 1963 were far less pronounced. It seems clear therefore that, for manufacturing at least, the estimated effect of the abolition of cartels in my 
regressions is unlikely to be biased because of the lack of a better control for the extent of foreign competition.

On the other hand, CHANGE might be positively correlated with foreign competition in the full sample, since most services industries were both relatively immune from imports and little affected by the 1956 cartel law. One response to this concern is to estimate the model for the full sample as well as for the manufacturing sub-sample and check whether the results differ in the two cases. In fact, the results for manufacturing constitute a more general robustness test in the present context for the reasons discussed in the previous section. In addition, I will check below whether my results change when the import penetration ratio is included among the regressors. Although import penetration cannot capture the effect of the mere threat of imports, may not reflect competitive pressure if imported goods are partly complementary to domestic products, is effectively only available for manufacturing industries and is clearly endogenous, this approach could provide additional reassurance that the main results of interest are not biased by any potential correlation between CHANGE and the intensity of foreign competition. ${ }^{4}$

My benchmark specification for STRIKES, the number of stoppages per 100,000 employees, is:

$$
\begin{aligned}
& \ln \text { STRIKES }_{i t}=\alpha_{i}+\mu_{t}+\beta_{1} \text { UNION }_{i, t-1}+\beta_{2} \ln \text { EMPLOYEES }_{i t}+\beta_{3} \text { UNEMPLOYMENT }_{i t} \\
& +\beta_{4} \text { CHANGE5964 }+\beta_{5} \text { CHANGE6570 }+\beta_{6} \text { CHANGE7175 }+u_{i t} \text {, }
\end{aligned}
$$

and similarly for DAYS, the number of working days lost per 1000 employees:

$$
\begin{aligned}
& \ln \text { DAYS }_{i t}=\alpha_{i}+\mu_{t}+\gamma_{1} \text { UNION }_{i, t-1}+\gamma_{2} \ln \text { EMPLOYEES }_{i t}+\gamma_{3} \text { UNEMPLOYMENT }_{i t} \\
& \\
&+\gamma_{4} \text { CHANGE5964 }+\gamma_{5} \text { CHANGE } 6570+\gamma_{6}{\text { CHANGE } 7175+\varepsilon_{i t} .}^{2}
\end{aligned}
$$

\footnotetext{
${ }^{4}$ An alternative candidate measure of the intensity of foreign competition is the rate of effective protection. However, estimates of effective rates of protection are available for only a few of the years in my sample.
} 
In these specifications, all industry-year pairs for which the number of stoppages and that of days lost are not recorded in the official statistics, for the reasons discussed in the previous section, were dropped from the sample. An alternative approach is to assume that both STRIKES and DAYS are equal to zero when their values are not reported. A complication with this approach is that a logarithmic transformation cannot be used for a variable that takes values of zero. Taking the cube root is sometimes regarded as a second-best option in such cases, since the distribution of the cube root has broadly similar properties to that of the logarithm when the original variable is highly skewed to the right. I therefore define root3STRIKES and root3DAYS, the cube roots of STRIKES and DAYS, respectively. The correlation coefficient between $\ln S T R I K E S$ and root3STRIKES (for non-zero values) is 0.94 and that between $\ln D A Y S$ and root3DAYS is 0.91 .

The variables CHANGE5964, CHANGE6570 and CHANGE7175 are measures of the competition effect on strike activity in different periods. The benchmark period for interpreting the coefficients on these variables is 1949-1958, a time when the British cartels where still in place. Recall that CHANGE takes a single value between 0 and 1 for each industry in the sample. CHANGE5964 is equal to CHANGE for all years between 1959 and 1964 and zero otherwise. Thus the coefficient on CHANGE5964 is a measure of the impact of cartel policy during the first six years of its implementation. Similarly, CHANGE6570 is equal to CHANGE for all years from 1965 to 1970 and zero otherwise, and measures the medium-term impact of the abolition of cartels. Finally CHANGE7175 is equal to CHANGE for all years between 1971 and 1975 and zero otherwise, and is a measure of the long-run effect of competition. Recall that although British industries started cancelling their collusive agreements in 1959, the process took many years to complete and in 
several cases competition did not emerge until after the mid-1960s. Although the division of the overall period 1959-1975 that I apply here may seem arbitrary, the econometric results are not much affected by small variations in the sub-periods used, and some division of this kind is necessary for analysing the timing of the effects of competition.

The control variables include the fraction of unionised employees, UNION; the logarithm of the number of employees in employment, $\ln E M P L O Y E E S$; and the unemployment rate, UNEMPLOYMENT. All three are measured at the industry level. Data on union density were taken from Bain and Price (1980), on employment and unemployment from the Ministry of Labour Gazette and the Annual Abstract of Statistics. Union density, which is available either for the same industry definitions as the stoppage data or sometimes at a slightly higher level of aggregation, is a measure of employees' ability to organise and carry out effective strikes. I use the lagged value of union density to mitigate any potential endogeneity concerns. The number of employees can be seen as a measure of productive activity, and therefore of the cost of a breakdown in negotiations for employers, following an influential theoretical argument that relates strike incidence to the joint costs of striking (Reder and Neumann 1980, McConnell 1990); alternatively, it could be a measure of the cost to employers of accepting a wage rise. The former interpretation would suggest a negative effect on strike incidence, the latter a positive one, and it is not clear which, if any, of these might dominate. The unemployment rate - defined here as the number of employees out of work who were previously employed in the industry in question as a fraction of the total number of employed and unemployed - has been widely used in previous studies as an inverse measure of the bargaining power of unions or as an index of the cost of striking for employees. Note that the inclusion of 
these variables in the regressions also serves as a control against potential omitted variable bias, if, for instance, collusion in the 1950s was more prevalent in declining or more unionised industries. The list of control variables is not very long because of data limitations, although three more variables - industry profitability, import penetration and the inflation rate - will be introduced in robustness checks below. However, the inclusion of a full set of industry and year dummies helps to control for a range of macroeconomic, industry-specific, institutional and political factors in these regressions.

I do not include a wage variable in my specifications. One reason is that the data set is not suited to modelling wage effects on strike activity. The data are industry-level and annual, so contemporaneous wages would clearly be endogenous and lagged industry wages largely irrelevant. More generally, I estimate here a reduced-form model and focus on long-term exogenous determinants of trends in strike activity rather than short-run fluctuations or micro-level heterogeneity. In this context wages are best seen as another outcome of collective bargaining, along with stoppages, rather than as a cause of disputes. In any case, the average industry wage is not correlated with CHANGE in these data. In my previous work on the effects of the 1956 Restrictive Trade Practices Act, using both cross-section and panel data for manufacturing industries at the three-digit level of aggregation, I have found no evidence of any effect of cartels or cartel policy on average wages and earnings (Symeonidis 2008, 2015). Thus the estimated effect of competition on strikes in the present work is unlikely to be biased because of the omission of a measure of earnings from the regressions.

Note that the above specifications are not meant to tell us anything about the level of strike intensity across industries in any given year, since industry effects are 
included among the regressors. My approach examines the evolution of the number of strikes and days lost across industries, and seeks to identify the extent to which this evolution was influenced by the change in competitive conditions facing firms in a wide range of industries.

A potential concern is that CHANGE might be endogenous. In other words, any differences in the evolution of strike intensity after 1958 across industries with different values of CHANGE might be partly driven by unobserved characteristics that differ across industries and are correlated with CHANGE rather than the 1956 law. It is difficult to find suitable instruments for CHANGE. However, there are several good reasons to believe that this is not a serious problem in the present context. First, Table 3 suggests that the difference in the evolution of strike intensity during the 1950s between industries which were subsequently significantly affected by cartel policy and those not much affected is minimal. This will be confirmed by the econometric results below. Therefore the comparison of different industries after 1958 will not be biased by any pre-existing trend differentials. Second, recall that a low or zero value of CHANGE can occur either because an industry was mostly or fully competitive throughout the period under study, as was the case for several manufacturing and a few non-manufacturing industries, or because it was collusive or under public ownership and not significantly affected by the 1956 legislation, as was the case for many services industries. It is very difficult to think of unobserved industry characteristics which might be positively associated with collusion in one set of industries, competition in another set of industries and public ownership in still another set of industries. Third, even if CHANGE were influenced by unobserved variables correlated with strike activity and not included in the model, these variables would be more likely to be part of the industry-specific effects than 
of the error term, since the large majority of restrictive agreements were in operation for many years before the introduction of the 1956 law. Any such correlations between the industry-specific effects and the endogenous variables would not bias the regression coefficients in my fixed effects specifications.

Tables 4 and 5 present the results for STRIKES and DAYS, respectively, using a fixed effects model with cluster-robust standard errors. The random effects model is clearly rejected for STRIKES but not so clearly for DAYS. The two sets of results do not differ significantly, and I report here fixed effects estimates throughout for consistency and random effects estimates for some specifications to allow for a comparison. The Wooldridge test for serial correlation in panel data typically does not reject the null hypothesis of no first-order autocorrelation, a result which is stronger for DAYS than for STRIKES. The absence of serial correlation may be partly due to the inclusion of time dummies among the regressors. As the test is somewhat ambiguous for STRIKES, all the standard errors reported are robust to heteroskedasticity as well as serial correlation. Alternative results obtained from a fixed effects model with AR(1) disturbances are presented for some specifications.

The first column in Table 4 contains the results from my benchmark model for lnSTRIKES, whereas the second column presents estimates from a model with AR(1) disturbances. In the third column I add CHANGE4953, which is equal to CHANGE for all years between 1949 and 1953 and zero otherwise. Thus the benchmark period in this regression is 1954-1958, the last few years of cartelisation. My aim in doing this is twofold: first, to confirm the absence of a statistically significant association between CHANGE and $\operatorname{lnSTRIKES}$ before the implementation of cartel policy, and, second, to check the robustness of my results for the effect of competition on $\ln S T R I K E S$ to a change in the benchmark period which could be relevant for several reasons. For 
instance, although most British cartels were long-standing, the registration of agreements took place after 1956, so any measurement error in CHANGE may be lower for 1954-1958 than for 1949-1953.

In the fourth column of Table 4 I restrict the sample to the 34 manufacturing industries and I also add a measure of industry profitability which is available for this group but not for most industries outside manufacturing. In particular, PROFIT is the rate of return on net assets (i.e. gross trading profit plus dividends and interest received plus other income minus depreciation divided by total net assets), computed from aggregated data for quoted UK companies reported in Goudie and Meeks (1986). Although the rate of return is an endogenous variable and the coefficient on PROFIT may be therefore interpreted as a correlation coefficient, its inclusion in the model is meant to confirm that any effect of product market competition on strike activity works independently of the level of profitability. The fifth column in Table 4 introduces import penetration, IMPORT, as an additional regressor. Note that IMPORT, which is defined as the ratio of imports to total sales by domestic firms and can be constructed only for manufacturing industries because of data limitations, is an endogenous variable and its inclusion in the model only serves to provide additional reassurance of lack of bias in the estimated effect of CHANGE on strike intensity. ${ }^{5}$

\footnotetext{
${ }^{5}$ I follow Hughes and Thirlwall (1977) in using the ratio of imports to total sales by domestic firms, $I / S$, as my measure of import penetration rather than an alternative measure, the ratio of imports to total sales in the domestic market (i.e. total sales by domestic firms plus imports minus exports), $I /(S+I-X)$. Unlike this alternative measure, $I / S$ is not affected by a change in $X$ when $I$ and $S$ remain constant - for instance, by a redirection of a part of domestic output into exports. In any case, the results using $I /(S+I-X)$ are very similar. The data on the value of imports and sales revenue of UK firms were obtained from the Annual Abstract of Statistics, the Annual Statement of the Trade of the United Kingdom, Overseas Trade Analysed in Terms of Industries (covering the years 1970 to 1975), the Historical Record of the Census of Production 1907 to 1970, and the annual Censuses of Production from 1970 to 1975. Because of gaps in the
} 
Results are also presented in the sixth column of Table 4 for a sample of 48 industries, excluding port and inland water transport and coal mining, both of which were declining industries largely or wholly under public ownership and not affected by the 1956 cartel law. Coal mining was by far the most strike-prone British industry during much of the period under study, and one where industrial action has been declining in the 1960s, unlike most of the rest of the economy. Port and inland water transport was also one of the most-strike intensive industries and experienced a surge in strike action in the late 1960s and early 1970s far greater than that experienced by any other British industry. This regression is therefore intended as a robustness check when two industries that appear to somewhat stand out from the rest are excluded from the sample. As a further robustness check, lnSTRIKES is replaced by root3STRIKES in the last three columns of Table 4 and a slightly larger sample that includes observations with zero stoppages is used.

Table 5 repeats the regressions of Table 4 with $\ln D A Y S$ and root $3 D A Y S$ as dependent variables, except that the model with AR(1) disturbances is now dropped in favour of a standard random effects model.

There is clear evidence from all specifications and samples of a strong positive effect of product market competition on the number of stoppages as well as the number of working days lost both in the short run and in the long run. The effect is robust to changes in the endogenous variable, the sample used, the estimation method, the benchmark period and the control variables. The coefficients on CHANGE5964, CHANGE6570 and CHANGE7175 are almost everywhere statistically significant, typically at the $5 \%$ or $1 \%$ level. The estimated coefficients suggest that a change of annual sales data and difficulties in matching certain product definitions across the various sources, some of the import penetration figures are approximate. 
competition regime that affects an additional $10 \%$ of an industry increases STRIKES by $7-10 \%$ and DAYS by about $15 \%$, on average, in that industry. Recall that the mean value of CHANGE across the 50 industries in my sample is 0.27 . My estimates therefore suggest that the intensification of competition following the abolition of the British cartels caused, on average, a $20-30 \%$ increase in the number of stoppages and a much larger increase in the number of working days lost over the following 15 to 20 years, a substantial effect. For manufacturing, the mean value of CHANGE is 0.43 , suggesting a $30-40 \%$ increase in the number of stoppages as a result of cartel policy. Note that the exclusion of coal mining and port and inland water transport reduces only slightly some of the coefficients on CHANGE5964, CHANGE6570 and CHANGE7175, and the effect of competition on $\ln D A Y S$ and $\ln S T R I K E S$ remains statistically significant in the short run as well as in the long run.

The coefficient on CHANGE4953 is statistically not significant, even at the $20 \%$ level, in all models except one, confirming that the positive association between competition and strike activity is a causal link, not a continuation of pre-existing differential trends. In one model where the coefficient on CHANGE4953 is statistically significant at the $10 \%$ level, it has the same sign as the coefficient on CHANGE5964. This suggests that even if industries with high value of CHANGE and industries with low value of CHANGE did have different trends until 1958 which are imprecisely estimated, these were, if anything, reversed after 1958. Of all the control variables, only union density appears to be positively associated with the number of stoppages and especially with the number of days lost, as expected. Unemployment does not seem to have an effect on strike activity. The result for profitability should be interpreted with some caution because PROFIT is only available at a slightly higher level of aggregation than the stoppage data (for about 20 different manufacturing 
industry groups). On the other hand, it is unlikely that the lack of a more precise measure of profitability, or the omission of this variable in regressions with the full sample, causes any bias to the estimated effect of competition: I have shown elsewhere that the breakdown of the British cartels did not have a significant effect on industry profitability because market structure adjusted through mergers and exit of firms to restore average profitability in industries that experienced a change of competition regime (Symeonidis 2002, chapter 7).

The coefficients on the year dummies (not reported) are large and statistically significant from 1960 and especially from 1968 onwards, in line with evidence reported in previous studies (for instance, Pencavel 1970) of an upward trend in strike activity during much of the period examined. In fact, dropping the time dummies reduces the $\mathrm{R}^{2}$ by about one third for $\ln S T R I K E S$ and by $10 \%$ for $\ln D A Y S$ (and causes the coefficients on CHANGE5964, CHANGE6570 and CHANGE7175 to more than double). In further robustness checks for the full sample as well as for the manufacturing sub-sample reported in Table 6, I replace the year dummies with a linear time trend, TREND, and add the annual inflation rate, INFLATION, among the regressors. A linear time trend may impose too much structure on the data, so I do not regard this specification as an alternative to those used for Tables 4 and 5 . Still, it may be useful as an additional robustness check which, unlike my benchmark model with year dummies, also allows me to explore potential links between industrial conflict and economywide variables such as inflation. The coefficients and t-statistics on CHANGE5964, CHANGE6570 and CHANGE7175 are not significantly affected, there is once again strong evidence of an upward trend in strike activity over time, and the inflation rate has a positive and statistically significant effect on $\ln D A Y S$ but not on $\ln S T R I K E S$. 
Two $\mathrm{R}^{2 \text { s }}$ are reported for each fixed effects regression in Tables 4-6. The difference between the two is a measure of the explanatory power of the industry effects, which is significant, especially for $\ln D A Y S$. This is consistent with the large and persistent differences in strike incidence across industries which are evident in the data. Note that the industry effects have a bigger impact than the time effects on working days lost, whereas the reverse is the case for the number of stoppages. Overall, the $\mathrm{R}^{2}$ 's indicate that my explanatory variables, including the time and industry effects, explain about $85 \%$ of the variation in the number of stoppages and $65 \%$ of the variation in working days lost.

\section{Discussion.}

This research has examined the impact of product market competition on strike activity using evidence from a natural experiment of policy reform, the introduction of cartel law in Britain. Taking advantage of the fact that different industries were affected to varying degrees by cartel policy, and using panel data for a 27-year period before and after the implementation of the legislation, the analysis has established that both the number of stoppages and the number of working days lost as a result of stoppages increased significantly when competition intensified after the breakdown of cartels in the short run as well as in the long run. The estimated effect of competition is large, statistically significant and robust to variations in the endogenous variable, the sample and the econometric specification, unlike that of several other potential determinants of strikes which have often appeared in the previous literature. The effect is also robust to controlling for industry profitability, which in any case is not related to competition in these data. In other words, competition is not simply an inverse measure of average profits in the present case. 
My econometric estimates suggest that the intensification of competition after the abolition of cartels caused, on average, about a 30\% increase in the number of stoppages and an even larger increase in the number of working days lost over the following 15 to 20 years. Admittedly, this effect should be seen in context: this was a time when the average number of stoppages across British industries more than doubled and the average number of working days lost more than tripled. The relatively high level of industrial conflict in Britain during the 1960s and 1970s is not necessarily unusual if one adopts a long-term view of industrial relations spanning one or two centuries rather than a few decades only. Nevertheless, it is legitimate to ask whether product market competition can have an equally strong effect on strike activity at times and places characterised by more modest levels of conflict. The answer to this question may well be yes. This paper has shown that several other economic variables which are often regarded as standard determinants of strikes had a lot less impact on industrial action in Britain during the 1960s and 1970s than competition. There is no reason to expect that the ranking of economic factors according to their relative significance as determinants of strike incidence should be any different at other times or countries.

What could be the economic mechanism driving my results? According to one hypothesis, competition reduces the ability of firms to pass on cost increases to prices and therefore makes them more resistant to union demands for improved pay or working conditions, thus triggering more and possibly longer strikes. Competition also puts pressure on firms to improve efficiency by internal reorganisation, which often goes against the interests or established practices of employees, creates insecurity and could result in more disputes. These arguments are theoretically unsatisfactory because a firm with market power may have a greater ability not only to meet union demands but also to resist them. And they also fail at a more fundamental level, since it is not 
clear why rational firms and unions should be unable, under conditions of perfect information, to reach an agreement without incurring the costs of a strike, irrespective of the firm's ability to pay and the union's ability to appropriate - in other words, irrespective of the degree of competition in the product market.

I propose here an interpretation that draws on theoretical models of bargaining with asymmetric information. There are a number of such models, but most are based on the idea that a union has worse information than a firm about the firm's profitability and hence its ability to meet the union's demands (see, for instance, Hayes 1984, Hart 1989, Tracy 1987, and Booth and Cressy 1990; as well as Kennan 2008 for a brief survey). The union may overestimate the firm's profitability and demand too high a wage, whereas a highly profitable firm has an incentive to misrepresent its financial position and offer too low a wage. In this context, a strike is a mechanism that reveals the firm's profitability to the union over time: the higher the profit, the more eager will the firm be to avoid a prolonged confrontation. Strikes must sometimes occur because if the union were never to strike, the firm would always offer the lowest possible wage. An obvious implication of these ideas is that strike incidence and duration increases with the degree of the union's uncertainty about firm profitability and therefore with profit dispersion across firms in an industry or profit volatility of a firm over time, a prediction supported by empirical evidence (Tracy 1986, 1987). Note that unlike this unambiguous result, the predictions of asymmetric information models about the association between the level of profitability and strike activity are less clear - for instance, Tracy (1987) predicts a negative link, whereas Booth and Cressy (1990) a positive one. Therefore the fact that no clear correlation emerges between industry profitability and industrial action 
in the present case is not inconsistent with my proposed interpretation (and is consistent with most previous empirical evidence).

Economic theory and empirical evidence suggest that profit dispersion and volatility both increase with the intensity of competition. Raith (2003) has shown that an increase in market size or the degree of product substitutability, which reduces prices and may therefore be seen as an intensification of competition, raises the volatility of firms’ profits in a principal-agent model of oligopoly with free entry. Boone (2008a, 2008b) has established that a common property of several different measures of competition across a range of theoretical models is that they involve an increase in “relative profit differences”, a measure closely related to profit dispersion across firms. Gaspar and Massa (2006) present evidence of a negative association between a firm's market power and the idiosyncratic volatility of its stock returns in a large sample of firms over four decades. They examine the channels through which this effect works and find that competition raises both profit volatility and uncertainty about average profitability. Comin and Philippon (2006) have also provided evidence of a positive relationship between competition and firm-level volatility.

In summary, my suggestion is that by increasing uncertainty, profit dispersion across firms and firm-level volatility, competition widens the informational asymmetry between firms and unions in bargaining, thus leading to more strikes. A formal test of this hypothesis would require firm-level data on strike activity and profitability, which are not available in the present context. Interestingly, in previous work (Symeonidis 2015) I have found evidence of a negative effect of collusion on the intra-industry dispersion of plant average earnings in 1950s Britain, a finding that seems consistent with the mechanism I have described above to interpret the strong positive effect of the abolition of the British cartels on industrial disputes. A potential concern is that my data 
set includes a number of industries fully or mostly under public ownership and subject to centralised industry-level bargaining, and for these industries the mechanism proposed here might not apply. However, I have shown that my results also hold for the manufacturing sub-sample, which only includes industries fully or mostly under private ownership and subject to an informal but effective system of bargaining at plant level that operated alongside centralised bargaining during the period under study. Furthermore, the industries which were under public ownership were not affected by the breakdown of cartels, so they do not influence the estimated effect of competition in my regressions using the full sample other than as part of the control group.

In previous research (Symeonidis 2000, 2002) I have shown that cartel policy in the UK caused a substantial restructuring of previously collusive industries through mergers and exit of firms, and that this process went on for more than a decade. It seems that firm-union bargaining became more difficult in these times of increased uncertainty and remained so in the long run, leading to a permanent rise in industrial action in previously collusive industries, at least until other factors - including macroeconomic, labour market, legislative and institutional changes in the 1980s and 1990s - caused a sharp decline of all industrial conflict in Britain. 
Table 1. Descriptive statistics for STRIKES and DAYS.

\begin{tabular}{|c|c|c|c|c|c|}
\hline STRIKES & Mean & Median & $\begin{array}{l}\text { Standard } \\
\text { deviation }\end{array}$ & Minimum & Maximum \\
\hline $\begin{array}{l}1949-1953 \\
(\mathrm{n}=250)\end{array}$ & 6.16 & 2.09 & 19.25 & 0 & 164.4 \\
\hline $\begin{array}{l}1954-1958 \\
(\mathrm{n}=250)\end{array}$ & 8.65 & 1.80 & 34.40 & 0 & 280.8 \\
\hline $\begin{array}{l}1959-1964 \\
(\mathrm{n}=300)\end{array}$ & 10.68 & 4.18 & 28.04 & 0 & 238.8 \\
\hline $\begin{array}{l}1965-1970 \\
(\mathrm{n}=300)\end{array}$ & 15.49 & 7.48 & 28.41 & 0 & 305.4 \\
\hline $\begin{array}{l}1971-1975 \\
(\mathrm{n}=250)\end{array}$ & 17.30 & 10.67 & 22.44 & 0 & 169.0 \\
\hline DAYS & Mean & Median & $\begin{array}{l}\text { Standard } \\
\text { deviation }\end{array}$ & Minimum & Maximum \\
\hline $\begin{array}{l}1949-1953 \\
(\mathrm{n}=250)\end{array}$ & 98.05 & 12.49 & 306.45 & 0 & 3123.8 \\
\hline $\begin{array}{l}1954-1958 \\
(\mathrm{n}=250)\end{array}$ & 223.04 & 12.73 & 800.47 & 0 & 7411.6 \\
\hline $\begin{array}{l}1959-1964 \\
(\mathrm{n}=300)\end{array}$ & 187.79 & 25.51 & 605.60 & 0 & 8760.9 \\
\hline $\begin{array}{l}1965-1970 \\
(\mathrm{n}=300)\end{array}$ & 325.26 & 68.55 & 857.79 & 0 & 8854.2 \\
\hline $\begin{array}{l}1971-1975 \\
(\mathrm{n}=250)\end{array}$ & 778.25 & 158.92 & 2593.76 & 0 & 32721.2 \\
\hline
\end{tabular}

Note: $\mathrm{n}$ denotes the number of observations (industry-year pairs). 
Table 2. Descriptive statistics for STRIKES and DAYS (manufacturing sub-sample).

\begin{tabular}{|c|c|c|c|c|c|}
\hline STRIKES & Mean & Median & $\begin{array}{l}\text { Standard } \\
\text { deviation }\end{array}$ & Minimum & Maximum \\
\hline $\begin{array}{l}1949-1953 \\
(\mathrm{n}=170)\end{array}$ & 3.58 & 2.54 & 4.26 & 0 & 34.6 \\
\hline $\begin{array}{l}1954-1958 \\
(n=170)\end{array}$ & 3.45 & 2.10 & 4.82 & 0 & 32.0 \\
\hline $\begin{array}{l}1959-1964 \\
(\mathrm{n}=204)\end{array}$ & 6.88 & 4.59 & 7.22 & 0 & 42.1 \\
\hline $\begin{array}{l}1965-1970 \\
(n=204)\end{array}$ & 13.36 & 9.14 & 13.81 & 0 & 67.9 \\
\hline $\begin{array}{l}1971-1975 \\
(\mathrm{n}=170)\end{array}$ & 16.62 & 14.32 & 11.92 & 0 & 59.8 \\
\hline DAYS & Mean & Median & $\begin{array}{l}\text { Standard } \\
\text { deviation }\end{array}$ & Minimum & Maximum \\
\hline $\begin{array}{l}1949-1953 \\
(\mathrm{n}=170)\end{array}$ & 71.02 & 13.69 & 158.24 & 0 & 1190.2 \\
\hline $\begin{array}{l}1954-1958 \\
(n=170)\end{array}$ & 153.52 & 14.30 & 629.45 & 0 & 7411.6 \\
\hline $\begin{array}{l}1959-1964 \\
(n=204)\end{array}$ & 203.66 & 35.30 & 689.20 & 0 & 8760.9 \\
\hline $\begin{array}{l}1965-1970 \\
(n=204)\end{array}$ & 267.62 & 78.73 & 524.07 & 0 & 4429.4 \\
\hline $\begin{array}{l}1971-1975 \\
(\mathrm{n}=170)\end{array}$ & 622.17 & 215.03 & 927.33 & 0 & 5781.9 \\
\hline
\end{tabular}

Note: $\mathrm{n}$ denotes the number of observations (industry-year pairs). 
Table 3. Correlation coefficients between CHANGE, $\operatorname{lnSTRIKES}$ and $\ln D A Y S$.

\section{Correlation coefficient between \\ CHANGE and $\ln S T R I K E S$}

Correlation coefficient between

CHANGE and $\ln D A Y S$
Correlation coefficient between $\ln S T R I K E S$ and $\ln D A Y S$

Full sample

1949-1953

$-0.014$

$-0.149$

0.747

( $\mathrm{n}=216)$

1954-1958

$-0.061$

$-0.101$

0.749

( $\mathrm{n}=218)$

1959-1964

0.098

0.068

0.792

( $\mathrm{n}=280)$

1965-1970

0.143

0.071

0.795

( $\mathrm{n}=285)$

1971-1975

0.215

0.131

0.782

( $\mathrm{n}=249)$

\section{Manufacturing}

sub-sample

1949-1953

$-0.141$

$-0.263$

0.688

( $\mathrm{n}=146)$

1954-1958

$-0.220$

$-0.191$

0.665

( $\mathrm{n}=146)$

1959-1964

( $\mathrm{n}=189$ )

$-0.079$

$-0.029$

0.737

1965-1970

0.008

0.088

0.860

( $\mathrm{n}=191)$

1971-1975

0.060

$-0.016$

0.717

Note: $\mathrm{n}$ denotes the number of observations (industry-year pairs). 
Table 4. Regression results for the number of stoppages per 100,000 employees.

\begin{tabular}{|c|c|c|c|c|c|c|c|c|c|}
\hline \multirow[b]{2}{*}{ UNION } & \multicolumn{6}{|c|}{$\begin{array}{c}\text { Dependent variable: } \\
\text { lnSTRIKES }\end{array}$} & \multicolumn{3}{|c|}{$\begin{array}{l}\text { Dependent variable: } \\
\text { root3STRIKES }\end{array}$} \\
\hline & $\begin{array}{l}1.315 \\
(1.78)\end{array}$ & $\begin{array}{l}1.049 \\
(2.08)\end{array}$ & $\begin{array}{l}1.242 \\
(1.66)\end{array}$ & $\begin{array}{l}0.608 \\
(0.51)\end{array}$ & $\begin{array}{l}0.453 \\
(0.39)\end{array}$ & $\begin{array}{l}1.370 \\
(1.93)\end{array}$ & $\begin{array}{l}0.795 \\
(1.14)\end{array}$ & $\begin{array}{l}0.620 \\
(1.63)\end{array}$ & $\begin{array}{l}0.729 \\
(1.02)\end{array}$ \\
\hline $\ln E M P L O Y E E S$ & $\begin{array}{l}0.362 \\
(1.36)\end{array}$ & $\begin{array}{l}0.206 \\
(1.48)\end{array}$ & $\begin{array}{l}0.369 \\
(1.36)\end{array}$ & $\begin{array}{l}0.206 \\
(0.58)\end{array}$ & $\begin{array}{l}0.234 \\
(0.69)\end{array}$ & $\begin{array}{l}0.253 \\
(1.09)\end{array}$ & $\begin{array}{l}0.259 \\
(1.13)\end{array}$ & $\begin{array}{l}0.300 \\
(2.72)\end{array}$ & $\begin{array}{l}0.245 \\
(1.14)\end{array}$ \\
\hline UNEMPLOYMENT & $\begin{array}{l}-8.753 \\
(-1.31)\end{array}$ & $\begin{array}{l}-4.815 \\
(-1.68)\end{array}$ & $\begin{array}{l}-8.716 \\
(-1.30)\end{array}$ & $\begin{array}{l}2.522 \\
(0.42)\end{array}$ & $\begin{array}{l}3.056 \\
(0.52)\end{array}$ & $\begin{array}{l}-1.271 \\
(-0.28)\end{array}$ & $\begin{array}{l}-7.512 \\
(-1.09)\end{array}$ & $\begin{array}{l}-3.882 \\
(-1.74)\end{array}$ & $\begin{array}{l}-7.499 \\
(-1.08)\end{array}$ \\
\hline CHANGE4953 & - & - & $\begin{array}{l}0.348 \\
(1.26)\end{array}$ & $\begin{array}{l}0.407 \\
(1.46)\end{array}$ & $\begin{array}{l}0.416 \\
(1.48)\end{array}$ & - & - & - & $\begin{array}{l}0.311 \\
(1.93)\end{array}$ \\
\hline CHANGE5964 & $\begin{array}{l}0.517 \\
(2.31)\end{array}$ & $\begin{array}{l}0.561 \\
(2.64)\end{array}$ & $\begin{array}{l}0.689 \\
(2.94)\end{array}$ & $\begin{array}{l}0.613 \\
(1.73)\end{array}$ & $\begin{array}{l}0.619 \\
(1.72)\end{array}$ & $\begin{array}{l}0.533 \\
(2.32)\end{array}$ & $\begin{array}{l}0.383 \\
(2.15)\end{array}$ & $\begin{array}{l}0.431 \\
(2.73)\end{array}$ & $\begin{array}{l}0.536 \\
(2.97)\end{array}$ \\
\hline CHANGE6570 & $\begin{array}{l}0.494 \\
(1.82)\end{array}$ & $\begin{array}{l}0.464 \\
(2.08)\end{array}$ & $\begin{array}{l}0.668 \\
(2.20)\end{array}$ & $\begin{array}{l}0.857 \\
(2.06)\end{array}$ & $\begin{array}{l}0.866 \\
(2.08)\end{array}$ & $\begin{array}{l}0.421 \\
(1.71)\end{array}$ & $\begin{array}{l}0.401 \\
(1.60)\end{array}$ & $\begin{array}{l}0.503 \\
(3.02)\end{array}$ & $\begin{array}{l}0.556 \\
(2.17)\end{array}$ \\
\hline CHANGE7176 & $\begin{array}{l}0.761 \\
(2.45)\end{array}$ & $\begin{array}{l}0.656 \\
(2.72)\end{array}$ & $\begin{array}{l}0.939 \\
(2.79)\end{array}$ & $\begin{array}{l}0.933 \\
(1.98)\end{array}$ & $\begin{array}{l}0.979 \\
(2.01)\end{array}$ & $\begin{array}{l}0.605 \\
(2.17)\end{array}$ & $\begin{array}{l}0.754 \\
(2.71)\end{array}$ & $\begin{array}{l}0.703 \\
(3.93)\end{array}$ & $\begin{array}{l}0.913 \\
(3.16)\end{array}$ \\
\hline PROFIT & - & - & - & $\begin{array}{l}0.129 \\
(0.16)\end{array}$ & $\begin{array}{l}0.218 \\
(0.27)\end{array}$ & - & - & - & - \\
\hline IMPORT & - & - & - & - & $\begin{array}{l}0.597 \\
(0.77)\end{array}$ & - & - & - & - \\
\hline Time dummies & Yes & Yes & Yes & Yes & Yes & Yes & Yes & Yes & Yes \\
\hline $\mathrm{R}^{2}$ & 0.634 & 0.455 & 0.635 & 0.679 & 0.680 & 0.657 & 0.525 & 0.360 & 0.527 \\
\hline $\mathrm{R}^{2}{ }_{\mathrm{LSDV}}$ & 0.882 & - & 0.882 & 0.816 & 0.817 & 0.868 & 0.846 & - & 0.847 \\
\hline Hausman statistic & 70.60 & - & 71.34 & 33.76 & 36.39 & 72.55 & 9.42 & - & 9.73 \\
\hline Prob-value & 0.000 & & 0.000 & 0.013 & 0.009 & 0.000 & 0.051 & & 0.045 \\
\hline Wooldridge test & 5.36 & - & 5.05 & 2.34 & 2.91 & 4.10 & 4.63 & - & 4.36 \\
\hline Prob-value & 0.025 & & 0.029 & 0.144 & 0.148 & 0.048 & 0.036 & & 0.042 \\
\hline $\mathrm{AR}(1)$ & - & 0.39 & - & - & - & - & - & 0.39 & - \\
\hline No. of industries & 50 & 50 & 50 & 34 & 34 & 48 & 50 & 50 & 50 \\
\hline $\begin{array}{l}\text { No. of } \\
\text { observations }\end{array}$ & 1248 & 1198 & 1248 & 841 & 841 & 1194 & 1350 & 1300 & 1350 \\
\hline
\end{tabular}

Notes: Columns 1, 3-6, 7 and 9: fixed effects estimation, t-statistics based on cluster-robust standard errors in parentheses. Columns 2 and 8: fixed effects estimation with AR(1) disturbances, t-statistics in parentheses. 
Table 5. Regression results for working days lost per 1000 employees.

\begin{tabular}{|c|c|c|c|c|c|c|c|c|c|}
\hline \multirow{3}{*}{ UNION } & \multicolumn{6}{|c|}{$\begin{array}{l}\text { Dependent variable: } \\
\qquad \ln D A Y S\end{array}$} & \multicolumn{3}{|c|}{$\begin{array}{c}\text { Dependent variable: } \\
\operatorname{root} 3 D A Y S\end{array}$} \\
\hline & 2.933 & 2.992 & 2.334 & 2.178 & 2.136 & 2.988 & 5.768 & 5.711 & 5.190 \\
\hline & $(3.00)$ & $(3.02)$ & (1.49) & $(1.98)$ & (1.93) & $(2.84)$ & $(3.05)$ & $(3.01)$ & (3.83) \\
\hline \multirow[t]{2}{*}{$\ln E M P L O Y E E S$} & 0.528 & 0.522 & -0.022 & 0.289 & 0.289 & 0.470 & 0.364 & 0.367 & 0.215 \\
\hline & (1.18) & (1.17) & $(-0.05)$ & $(1.10)$ & $(1.10)$ & $(1.03)$ & $(0.59)$ & $(0.59)$ & $(0.66)$ \\
\hline \multirow[t]{2}{*}{ UNEMPLOYMENT } & 0.386 & 0.355 & 5.600 & 10.07 & 10.27 & 1.758 & 18.08 & 18.09 & 18.50 \\
\hline & $(0.06)$ & $(0.06)$ & $(0.64)$ & $(1.40)$ & $(1.44)$ & $(0.25)$ & $(1.47)$ & $(1.47)$ & $(1.47)$ \\
\hline \multirow[t]{2}{*}{ CHANGE4953 } & - & -0.282 & - & - & - & - & - & 0.270 & 0.280 \\
\hline & & $(-0.64)$ & & & & & & $(0.44)$ & $(0.53)$ \\
\hline \multirow[t]{2}{*}{ CHANGE5964 } & 1.392 & 1.253 & 1.636 & 1.387 & 1.392 & 1.363 & 2.059 & 2.191 & 2.178 \\
\hline & (3.78) & (3.03) & (3.96) & $(3.42)$ & $(3.43)$ & $(3.52)$ & $(4.86)$ & $(3.82)$ & $(4.12)$ \\
\hline \multirow[t]{2}{*}{ CHANGE6570 } & 1.124 & 0.983 & 2.376 & 2.112 & 2.120 & 1.070 & 1.438 & 1.573 & 1.588 \\
\hline & $(2.11)$ & $(1.77)$ & (3.88) & $(3.80)$ & $(3.82)$ & $(1.96)$ & $(2.39)$ & $(2.58)$ & $(2.65)$ \\
\hline \multirow[t]{2}{*}{ CHANGE7176 } & 1.466 & 1.321 & 1.466 & 1.200 & 1.228 & 1.388 & 1.600 & 1.740 & 1.767 \\
\hline & $(2.52)$ & $(2.11)$ & $(2.28)$ & $(2.09)$ & $(2.12)$ & $(2.29)$ & $(1.66)$ & $(1.72)$ & $(1.70)$ \\
\hline \multirow[t]{2}{*}{ PROFIT } & - & - & 1.607 & 1.097 & 1.200 & - & - & - & - \\
\hline & & & $(1.01)$ & $(0.72)$ & $(0.79)$ & & & & \\
\hline \multirow[t]{2}{*}{ IMPORT } & - & - & - & - & 0.421 & - & - & - & - \\
\hline & & & & & $(0.49)$ & & & & \\
\hline Time dummies & Yes & Yes & Yes & Yes & Yes & Yes & Yes & Yes & Yes \\
\hline $\mathrm{R}^{2}$ & 0.375 & 0.375 & 0.480 & 0.479 & 0.480 & 0.379 & 0.333 & 0.333 & 0.333 \\
\hline $\mathrm{R}_{\mathrm{LSDV}}^{2}$ & 0.676 & 0.676 & 0.686 & - & - & 0.649 & 0.651 & 0.651 & - \\
\hline Hausman statistic & 30.48 & 31.14 & 25.44 & 25.44 & 24.79 & 26.30 & 1.67 & 1.65 & 1.65 \\
\hline Prob-value & 0.046 & 0.053 & 0.147 & 0.147 & 0.168 & 0.122 & 0.796 & 0.800 & 0.800 \\
\hline Wooldridge test & 1.82 & 1.67 & 0.97 & - & - & 3.15 & 0.94 & 0.99 & - \\
\hline Prob-value & 0.183 & 0.202 & 0.333 & & & 0.082 & 0.337 & 0.324 & \\
\hline No. of industries & 50 & 50 & 34 & 34 & 34 & 48 & 50 & 50 & 50 \\
\hline $\begin{array}{l}\text { No. of } \\
\text { observations }\end{array}$ & 1248 & 1248 & 841 & 841 & 841 & 1194 & 1350 & 1350 & 1350 \\
\hline
\end{tabular}

Notes: Columns 1-3, 6 and 7-8: fixed effects estimation. Columns 4-5 and 9: random effects estimation. All columns: t-statistics based on cluster-robust standard errors in parentheses. 
Table 6. Further robustness checks.

\begin{tabular}{|c|c|c|c|c|c|c|}
\hline \multirow[b]{2}{*}{ UNION } & \multicolumn{3}{|c|}{$\begin{array}{c}\text { Dependent variable: } \\
\ln S T R I K E S\end{array}$} & \multicolumn{3}{|c|}{$\begin{array}{l}\text { Dependent variable: } \\
\qquad \ln D A Y S\end{array}$} \\
\hline & $\begin{array}{l}1.917 \\
(2.58)\end{array}$ & $\begin{array}{l}2.004 \\
(1.65)\end{array}$ & $\begin{array}{l}1.409 \\
(1.24)\end{array}$ & $\begin{array}{l}3.963 \\
(4.56)\end{array}$ & $\begin{array}{l}4.359 \\
(3.07)\end{array}$ & $\begin{array}{l}3.551 \\
(3.33)\end{array}$ \\
\hline $\ln E M P L O Y E E S$ & $\begin{array}{l}0.261 \\
(0.99)\end{array}$ & $\begin{array}{l}0.088 \\
(0.31)\end{array}$ & $\begin{array}{l}0.147 \\
(0.49)\end{array}$ & $\begin{array}{l}0.443 \\
(1.06)\end{array}$ & $\begin{array}{l}0.037 \\
(0.09)\end{array}$ & $\begin{array}{l}0.238 \\
(0.94)\end{array}$ \\
\hline UNEMPLOYMENT & $\begin{array}{l}-5.748 \\
(-1.40)\end{array}$ & $\begin{array}{l}3.548 \\
(0.92)\end{array}$ & $\begin{array}{l}1.976 \\
(0.52)\end{array}$ & $\begin{array}{l}4.329 \\
(0.85)\end{array}$ & $\begin{array}{l}15.81 \\
(2.37)\end{array}$ & $\begin{array}{l}17.65 \\
(3.07)\end{array}$ \\
\hline CHANGE4953 & - & - & $\begin{array}{l}0.973 \\
(4.74)\end{array}$ & - & - & - \\
\hline CHANGE5964 & $\begin{array}{l}0.561 \\
(3.03)\end{array}$ & $\begin{array}{l}0.610 \\
(2.64)\end{array}$ & $\begin{array}{l}0.898 \\
(3.96)\end{array}$ & $\begin{array}{l}0.892 \\
(2.84)\end{array}$ & $\begin{array}{l}1.209 \\
(3.47)\end{array}$ & $\begin{array}{l}1.039 \\
(2.97)\end{array}$ \\
\hline CHANGE6570 & $\begin{array}{l}0.968 \\
(4.11)\end{array}$ & $\begin{array}{l}1.127 \\
(3.42)\end{array}$ & $\begin{array}{l}1.364 \\
(4.16)\end{array}$ & $\begin{array}{l}1.216 \\
(2.72)\end{array}$ & $\begin{array}{l}1.659 \\
(3.36)\end{array}$ & $\begin{array}{l}1.497 \\
(3.17)\end{array}$ \\
\hline CHANGE7176 & $\begin{array}{l}0.721 \\
(2.38)\end{array}$ & $\begin{array}{l}0.618 \\
(1.34)\end{array}$ & $\begin{array}{l}1.032 \\
(2.27)\end{array}$ & $\begin{array}{l}1.250 \\
(2.18)\end{array}$ & $\begin{array}{l}1.068 \\
(1.53)\end{array}$ & $\begin{array}{l}1.024 \\
(1.63)\end{array}$ \\
\hline PROFIT & - & $\begin{array}{l}1.207 \\
(2.00)\end{array}$ & $\begin{array}{l}0.847 \\
(1.41)\end{array}$ & - & $\begin{array}{l}3.309 \\
(2.81)\end{array}$ & $\begin{array}{l}2.868 \\
(2.43)\end{array}$ \\
\hline IMPORT & - & $\begin{array}{l}0.687 \\
(1.01)\end{array}$ & $\begin{array}{l}0.702 \\
(0.99)\end{array}$ & - & $\begin{array}{l}0.926 \\
(0.95)\end{array}$ & $\begin{array}{l}0.734 \\
(0.87)\end{array}$ \\
\hline INFLATION & $\begin{array}{l}0.684 \\
(1.33)\end{array}$ & $\begin{array}{l}0.286 \\
(0.37)\end{array}$ & $\begin{array}{l}-0.235 \\
(-0.31)\end{array}$ & $\begin{array}{l}2.340 \\
(2.79)\end{array}$ & $\begin{array}{l}2.278 \\
(2.14)\end{array}$ & $\begin{array}{l}2.620 \\
(2.80)\end{array}$ \\
\hline Time dummies & No & No & No & No & No & No \\
\hline TREND & $\begin{array}{c}0.063 \\
(11.67)\end{array}$ & $\begin{array}{l}0.060 \\
(7.19)\end{array}$ & $\begin{array}{l}0.069 \\
(7.35)\end{array}$ & $\begin{array}{l}0.067 \\
(6.15)\end{array}$ & $\begin{array}{l}0.067 \\
(4.60)\end{array}$ & $\begin{array}{l}0.069 \\
(4.78)\end{array}$ \\
\hline $\mathrm{R}^{2}$ & 0.553 & 0.611 & 0.628 & 0.311 & 0.408 & 0.407 \\
\hline $\mathrm{R}_{\mathrm{LSDV}}{ }_{\mathrm{L}}$ & 0.856 & 0.777 & 0.787 & 0.642 & 0.643 & - \\
\hline Hausman statistic & 24.43 & 16.40 & 18.09 & 11.54 & 13.43 & 13.43 \\
\hline Prob-value & 0.001 & 0.059 & 0.053 & 0.116 & 0.144 & 0.144 \\
\hline No. of industries & 50 & 34 & 34 & 50 & 34 & 34 \\
\hline No. of observations & 1248 & 841 & 841 & 1248 & 841 & 841 \\
\hline
\end{tabular}

Notes: Columns 1-3 and 4-5: fixed effects estimation. Column 6: random effects estimation. All columns: t-statistics based on cluster-robust standard errors in parentheses. 


\begin{abstract}
APPENDIX
As pointed out in the text, the competition variable CHANGE takes values between 0 and 1 according to the fraction of each industry which was affected by the 1956 Restrictive Trade Practices Act. I illustrate here the construction of CHANGE from the primary information on collusive agreements by way of two examples. Both are manufacturing industries, as most non-manufacturing industries were not significantly affected by the 1956 cartel law, and both contain a variety of types of agreements and involve the use of several sources of information. A detailed survey of restrictive agreements across all British manufacturing industries from the early 1950s to the mid1970s can be found in Symeonidis (2002).
\end{abstract}

\title{
Bread, flour confectionery and biscuits
}

The three products of this industry are bread, accounting for about $40 \%$ of total industry sales revenue in the late 1950s and early 1960s according to detailed product-level data from the 1958 and 1963 Censuses of Production; flour confectionery, covering another $30 \%$ of total industry sales; and biscuits. The price of bread was under government control until the mid-1950s. It then became subject to various agreements by national, regional and local associations. The most important ones were a pricing agreement by the Federation of Wholesale and Multiple Bakers, whose members were "plant bakers" in England and Wales, and price agreements by the Wholesale and Retail Bakers of Scotland Association, the Scottish Association of Master Bakers, and a Joint Costing Committee of the two associations. All these were formally abandoned in 1959-1960. A range of regional agreements, as well as several others by various associations of “master bakers” and numerous local collusive arrangements, also ended at that time.

Swann et al. (1973) describe the gradual emergence of competition in the bread industry, despite parallel pricing and information agreements about discounts, which ended in 1965. Further information is contained in MMC, Flour and Bread (H.M.S.O., 
1977). A large number of restrictive arrangements among producers were in operation in the late 1960s or early 1970s. Most of them involved the exchange of information about discounts to particular buyers or about intended increases in discounts. Some were national, but most were local. All of them were abandoned in the mid-1970s. However, it is very doubtful that these arrangements had any significant effect on competition. The view of the MMC was that they were an attempt, largely unsuccessful, to resist pressure from retailers for progressively larger discounts. In fact, discounts kept rising between 1965 and 1975, which suggests that competition was largely effective.

Flour confectionery was not subject to any national agreements. However, some of the regional or local pricing arrangements among bakers covered flour confectionery as well, although most did not. A plausible estimate is that as much as a third of the flour confectionery industry was affected by the 1956 law. Finally, in biscuits an agreement by the National Association of Biscuit Manufacturers provided for prices, conditions of sale and restrictions on sales promotion, and was cancelled in 1959. Chocolate biscuits were also covered by agreements among chocolate confectionery manufacturers, which ended in the early 1960s. The biscuit industry was also subject to collective discrimination arrangements before 1956. Cereal filling, a secondary product of the industry, was subject to a pricing agreement, which was operated by the Rusk Manufacturers Association and was abandoned in 1960.

In summary, about $80 \%$ of the bread, flour confectionery and biscuit industry was subject to collusion in the 1950s and later became competitive, hence CHANGE takes the value 0.8 .

\section{Pharmaceutical and toilet preparations}

This industry includes three product categories: pharmaceutical chemicals, accounting for about $15 \%$ of total industry sales revenue in the late 1950s and early 1960s; pharmaceutical preparations, covering another 55\% of sales revenue; and toilet preparations. A restrictive agreement between two producers of insulin, providing for 
co-operation in production and for the joint sale of insulin, was cancelled in 1961. See also MRPC, Report on the Supply of Insulin (H.M.S.O., 1952). Insulin is a very small part of the industry, however. An agreement of the Chemists Federation was referred to the Restrictive Practices Court, contested by the parties but nevertheless condemned by the Court in late 1958. The membership of the Federation consisted of manufacturers of proprietary medicines, wholesale chemists and retail chemists. The Federation imposed restrictions designed to prevent the sale to the public by anyone except retail chemists (whether or not members) of proprietary medicines manufactured by members. Although this arrangement restricted competition among distributors, it is not clear why it should have had a significant effect on competition among producers. The same remark can be made about the activities of the Proprietary Articles Trade Association, whose membership consisted of manufacturers and distributors of medicines and toiletries: the Association collectively enforced resale prices and set minimum distributors’ margins until 1956, but it did not regulate the manufacturers’ individual prices. An agreement of the Proprietary Association of Great Britain, which remained in force throughout the period examined here, related only to a Code of Conduct. A pricing agreement between three UK and several foreign manufacturers of quinine and quinidine, which ended in 1963, covered a very specific product and was of little importance for the industry as a whole.

In contrast, an agreement by the Association of the British Pharmaceutical Industry, which ended in 1960, contained recommended prices for non-proprietary medicines for the home retail and hospital trade. The agreement did not affect branded proprietary drugs or export sales. According to a case study of the industry, written by C.J. Thomas and published in Burn (1958), roughly a third of total sales of pharmaceuticals in the mid-1950s were export sales; another third were home sales of branded and unbranded drugs through the National Health Service (either to hospitals or supplied on prescription), and about $70 \%$ of those were sales of branded drugs; and another third were publicly advertised proprietary medicines, drugs sold without 
prescription, and veterinary and horticultural medicines. These figures suggest that sales of unbranded drugs in the home market, either through the NHS or without prescription, did not account for more than $10-15 \%$ of total sales of pharmaceutical preparations in the mid-1950s, and they probably accounted for less than $10 \%$ in the 1960 s.

Finally, an agreement by the Hairdressing Manufacturers and Wholesalers Association specified conditions of sale and minimum trade discounts for hairdressers' articles. Most of the restrictions were abandoned in 1959. This association was also responsible for the collective enforcement of manufacturers' individual resale prices until 1956. Similarly, the Proprietary Articles Trade Association enforced resale prices and set minimum distributors’ margins for other toilet preparations until 1956. Although competition among distributors was certainly regulated by these arrangements, competition among manufacturers of toilet preparations was not.

In summary, about $10 \%$ of the pharmaceutical and toilet preparations industry experienced a change of competition regime, so CHANGE takes the value 0.1 . 


\section{REFERENCES}

Abowd, J.M. and J.S. Tracy (1989). Market structure, strike activity, and union wage settlements. Industrial Relations, 28: 227-250.

Bain, G.S. and R. Price (1980). Profiles of Union Growth. Oxford: Basil Blackwell. Boone, J. (2008a). A new way to measure competition. Economic Journal, 118: 12451261.

Boone, J. (2008b). Competition: theoretical parameterizations and empirical measures. Journal of Institutional and Theoretical Economics, 164: 587-611.

Booth A. and R. Cressy (1990). Strikes with asymmetric information: theory and evidence. Oxford Bulletin of Economics and Statistics, 52: 269-391.

Brandl, B. and F. Traxler (2010). Labour conflicts: a cross-national analysis of economic and institutional determinants, 1971-2002. European Sociological Review, 26: 519-540.

Burn, D., ed. (1958). The Structure of British Industry, 2 vols. Cambridge: Cambridge University Press.

Card, D. (1990). Strikes and bargaining: a survey of the recent empirical literature. American Economic Review, AEA Papers and Proceedings, 80: 410-415.

Comin, D.A. and T. Philippon (2006). The rise in firm-level volatility: causes and consequences. In M. Gertler and K. Rogoff, eds, NBER Macroeconomics Annual, vol. 20. Cambridge, MA: M.I.T. Press.

Cramton, P. and J. Tracy (2003). Unions, bargaining and strikes. In J.T. Addison and C. Schnabel, eds, International Handbook of Trade Unions. Cheltenham, UK: Edward Elgar.

Durcan, J.W., W.E.J. McCarthy and G.P. Redman (1983). Strikes in Post-war Britain. London: George Allen \& Unwin.

Franzosi, R. (1989). One hundred years of strike statistics: methodological and theoretical issues in quantitative strike research. Industrial and Labor Relations Review, 42: 348-362.

Gaspar, J.M. and M. Massa (2006). Idiosyncratic volatility and product market competition. Journal of Business, 79: 3125-3152.

Geroski, P.A., A. P. Hamlin and K. G. Knight (1982). Wages, strikes and market structure. Oxford Economic Papers, 34: 276-291. 
Geroski, P.A. and K. G. Knight (1983). Wages, strikes and market structure: some further evidence. Oxford Economic Papers, 35: 146-152.

Goudie, A.W. and G. Meeks (1986). Company Finance and Performance : Aggregated Financial Accounts for Individual British Industries, 1948-82. Department of Applied Economics, University of Cambridge.

Hart, O. (1989). Bargaining and strikes. Quarterly Journal of Economics, 104: 25-43.

Hart, P.E., Utton, M.A. and Walshe, G. (1973). Mergers and Concentration in British Industry. Cambridge: Cambridge University Press.

Hayes, B. (1984). Unions and strikes with asymmetric information. Journal of Labor Economics, 2: 57-83.

Hughes, J.J. and A.P. Thirlwall (1977). Trends and cycles in import penetration in the UK. Oxford Bulletin of Economics and Statistics, 39: 301-317.

Ingram, P., D. Metcalf and J. Wadsworth (1993). Strike incidence in British manufacturing in the 1980s. Industrial and Labor Relations Review, 46: 704-717.

Kaufman, B.E. (1982). The determinants of strikes in the United States, 1900-1977. Industrial and Labor Relations Review, 35: 473-490.

Kaufman, B.E. (1992). Research on strike models and outcomes in the 1980s: Accomplishments and shortcomings. In D. Lewin, O.S. Mitchell and P.D. Sherer, eds., Research Frontiers in Industrial Relations and Human Resources. Industrial Relations Research Association, University of Wisconsin.

Kennan, J. (1986). The economics of strikes. In O. Ashenfelter and R. Layard, eds, Handbook of Labor Economics, volume 2. Amsterdam: North-Holland.

Kennan, J. (2008). Strikes. In S. Durlauf and L. Blume, eds, The New Palgrave Dictionary of Economics. Basingstoke: Palgrave Macmillan.

Kerr, C. and A. Siegel (1954). The inter-industry propensity to strike: an international comparison. In A. Kornhauser, R. Dubin and A.M. Ross, eds, Industrial Conflict. New York: McGraw-Hill.

Kitchin, P.D. (1976). Effective rates of protection for United Kingdom manufacturing in 1963 and 1968. In M.J. Artis and A.R. Nobay, eds, Essays in Economic Analysis. Cambridge: Cambridge University Press.

Knight, K.G. (1972). Strikes and wage inflation in British manufacturing industry. Bulletin of the Oxford Institute of Economics and Statistics, 34: 281-294.

McConnell, S. (1990). Cyclical fluctuations in strike activity. Industrial and Labor Relations Review, 44: 130-143. 
Mumford, K. (1993). A critical comparison of models of strike activity. Oxford Bulletin of Economics and Statistics, 55: 285-312.

O'Mahony, M. and N. Oulton (1990). Industry-level estimates of the capital stock in UK manufacturing, 1948-85. NIESR Discussion Paper no. 172.

Pencavel, J.H. (1970). An investigation into industrial strike activity in Britain. Economica, 37: 239-255.

Political and Economic Planning (1957). Industrial Trade Associations. London: George Allen \& Unwin.

Raith, M. (2003). Competition, risk, and managerial incentives. American Economic Review, 93: 1425-1436.

Reder, M.W. and G.R. Neumann (1980). Conflict and contract: the case of strikes. Journal of Political Economy, 88: 867-886.

Rimlinger, G.V. (1959). International differences in the strike propensity of coal miners: experience in four countries. Industrial and Labor Relations Review, 12: 389-405.

Shorey, J. (1976). An inter-industry analysis of strike frequency. Economica, 43: 349366.

Shorey, J. (1977). Time series analysis of strike frequency. British Journal of Industrial Relations, 15: 63-75.

Smith, C.T.B., R. Clifton, P. Makeham, S.W. Creigh and R.V. Burn (1978). Strikes in Britain. Manpower paper no. 15, Department of Employment. London: H.M.S.O.

Swann, D., O'Brien, D.P., Maunder, W.P.J. and Howe, W.S. (1973). Competition in British Industry: Case Studies of the Effects of Restrictive Practices Legislation. Department of Economics, Loughborough University of Technology.

Swann, D., O'Brien, D.P., Maunder, W.P.J. and Howe, W.S. (1974). Competition in British Industry. London: George Allen \& Unwin.

Sutton, J. (1991). Sunk Costs and Market Structure. Cambridge, MA: M.I.T. Press.

Symeonidis, G. (2000). Price competition and market structure: the impact of cartel policy on concentration in the UK. Journal of Industrial Economics, 48: 1-26.

Symeonidis, G. (2002). The Effects of Competition. Cambridge, MA: M.I.T. Press.

Symeonidis, G. (2003). In which industries is collusion more likely? Evidence from the UK. Journal of Industrial Economics, 51: 45-74. 
Symeonidis, G. (2008). The effect of competition on wages and productivity: evidence from the UK. Review of Economics and Statistics, 90: 134-146.

Symeonidis, G. (2015). The effect of competition on the intra-industry dispersion of earnings. Oxford Economic Papers, 67: 433-454.

Tracy, J.S. (1986). An investigation into the determinants of U.S. strike activity. American Economic Review, 76: 423-436.

Tracy, J.S. (1987). An empirical test of an asymmetric information model of strikes. Journal of Labor Economics, 5: 149-173.

Van der Velden, S., H. Dribbusch, D. Lyddon and K. Vandaele, eds (2007). Strikes around the World, 1968-2005. Amsterdam: Aksant Academic Publishing. 